\title{
Simultaneous coronary artery bypass grafting and carotid endarterectomy can be performed with low mortality rates
}

\author{
Ebuzer Aydin ${ }^{1}$, Yucel Ozen ${ }^{1}$, Sabit Sarikaya ${ }^{1}$, Davut Cekmecelioglu ${ }^{1 *}$, Ismail Yukseltan² \\ From World Society of Cardiothoracic Surgeons 25th Anniversary Congress, Edinburgh \\ Edinburgh, UK. 19-22 September 2015
}

\section{Background/Introduction}

There remains a controversy on the best approach for patients with concomitant carotid and coronary artery disease.

\section{Aims/Objectives}

In this study, we report our experience with simultaneous carotid endarterectomy (CEA) and coronary artery bypass graft $(\mathrm{CABG})$ surgery in our clinic in the light of the literature data.

\section{Method}

Between January 1996 and January 2009, a total of 110 patients (86 males, 24 females; mean age: $65.11 \pm 7.81$ years; range, 44 to 85 years) who were admitted to hospital, Cardiovascular Surgery Clinic were retrospectively analyzed. All patients underwent simultaneous CEA and CABG. Demographic characteristics of the patients and a history of previous myocardial infarction (MI), hypertension, diabetes mellitus, hyperlipidemia, peripheral arterial disease, and smoking were recorded.

\section{Results}

One patient $(0.9 \%)$ with major stroke died due to ventricular fibrillation. Perioperative neurological complications were observed in seven patients (6\%). Complications were persistent in two patients. Four patients (3\%) had postoperative major stroke, whereas three patients $(2 \%)$ had transient hemiparesis. No perioperative myocardial infarction was observed.

${ }^{1}$ Kartal Kosuyolu Yuksek Ihtisas Research and Training Hospital, Istanbul,

Turkey

Full list of author information is available at the end of the article

\section{Discussion/Conclusion}

Simultaneous CEA and CABG can be performed with low mortality and morbidity.

\section{Authors' details}

'Kartal Kosuyolu Yuksek Ihtisas Research and Training Hospital, Istanbul,

Turkey. ${ }^{2}$ Taksim German Hospital, Istanbul, Turkey.

Published: 16 December 2015

doi:10.1186/1749-8090-10-S1-A301

Cite this article as: Aydin et al:: Simultaneous coronary artery bypass grafting and carotid endarterectomy can be performed with low mortality rates. Journal of Cardiothoracic Surgery 2015 10(Suppl 1):A301.
Submit your next manuscript to BioMed Central and take full advantage of:

- Convenient online submission

- Thorough peer review

- No space constraints or color figure charges

- Immediate publication on acceptance

- Inclusion in PubMed, CAS, Scopus and Google Scholar

- Research which is freely available for redistribution

Submit your manuscript at www.biomedcentral.com/submit
() Biomed Central 